\title{
Does obesity reduce risk for osteoporosis and fractures in older adults?
}

Dr. David Scott ${ }^{1,2}$, Professor Gustavo Duque ${ }^{2}$ and Professor Peter R. Ebeling, AO ${ }^{1}$

${ }^{1}$ Department of Medicine, School of Clinical Sciences at Monash Health, Faculty of Medicine, Nursing and Health Sciences, Monash University, Monash Medical Centre, 246

Clayton Road, Clayton, Victoria, Australia 3168

${ }^{2}$ Australian Institute for Musculoskeletal Science (AIMSS), Melbourne Medical School, The University of Melbourne, Sunshine Hospital, 176 Furlong Road, St Albans, Victoria, Australia 3021

\section{Corresponding author and address for reprints:}

Dr. David Scott

Department of Medicine, School of Clinical Sciences at Monash Health, Faculty of Medicine, Nursing and Health Sciences, Monash University, 246 Clayton Road, Clayton, Victoria, Australia, 3068.

Tel: + $61385722397 \quad$ Fax: + $61395946437 \quad$ E-mail: david.scott@monash.edu

Conflicts of Interest: No disclosures

This is the author manuscript accepted for publication and has undergone full peer review but has not been through the copyediting, typesetting, pagination and proofreading process, which may lead to differences between this version and the Version of Record. Please cite this article as doi: 10.1111/imj.13655

This article is protected by copyright. All rights reserved. 


\section{Dear Editor,}

We read with interest the review by Cheung and colleagues and agree that existing evidence for the obesity paradox is weak (1). We contend however that benefits of excessive adiposity for osteoporotic fractures are not supported by the literature, despite the authors' conclusion that obesity protects against fractures.

While obesity defined by body mass index (BMI) is generally associated with lower fracture incidence, fracture risk at specific sites may be increased. In the Global Longitudinal Osteoporosis in Women study, fracture prevalence and incidence were similar for obese and non-obese women, and risk of incident ankle and upper leg fractures were significantly higher in obese (2). Cheung et al note that BMI is a better indicator of lean than fat mass (1) and in over 43,000 Canadian older adults, higher lean mass was positively associated with femoral neck bone mineral density (BMD), whereas fat mass had no effect on BMD and adversely affected femoral strength index (3). Thus, higher lean mass, not fat mass, likely explains positive associations of higher BMI with BMD in older adults.

The authors identified that body fat distribution is more predictive of clinical outcomes than BMI (1), and this may be true for osteoporotic fractures. Men with higher levels of visceral adipose tissue have poorer bone mechanical properties, despite having similar BMD compared with those with low visceral adipose tissue (4). A recent metaanalysis also demonstrated that high waist circumference, a measure of abdominal adiposity, was associated with almost $60 \%$ increased relative risk of hip fracture (5).

Finally, while we agree that weight loss in obese older adults is beneficial for cardiometabolic health, clinicians should be aware that weight loss results in declines in muscle and bone mass that may increase falls and fracture risk. Incorporating exercise, particularly resistance training, into weight loss programs can significantly reduce the loss of muscle and bone mass (6), and is therefore strongly recommended for obese older adults. 


\section{References}

1. Cheung Y-M, Joham A, Marks S, Teede H. The obesity paradox: an endocrine perspective. Intern Med J. 2017;47(7):727-33.

2. Compston JE, Watts NB, Chapurlat R, Cooper C, Boonen S, Greenspan S, et al. Obesity is not protective against fracture in postmenopausal women: GLOW. American journal of medicine. 2011;124(11):1043-50.

3. Leslie WD, Orwoll ES, Nielson CM, Morin SN, Majumdar SR, Johansson H, et al. Estimated Lean Mass and Fat Mass Differentially Affect Femoral Bone Density and Strength Index But Are Not FRAX Independent Risk Factors for Fracture. Journal of Bone and Mineral Research. 2014.

4. Bredella MA, Lin E, Gerweck AV, Landa MG, Thomas BJ, Torriani M, et al. Determinants of Bone Microarchitecture and Mechanical Properties in Obese Men. Journal of Clinical Endocrinology \& Metabolism. 2012;97(11):4115-22.

5. Li X, Gong X, Jiang W. Abdominal obesity and risk of hip fracture: a meta-analysis of prospective studies. Osteoporosis International. 2017:1-11.

6. Villareal DT, Aguirre L, Gurney AB, Waters DL, Sinacore DR, Colombo E, et al. Aerobic or Resistance Exercise, or Both, in Dieting Obese Older Adults. N Engl J Med. 2017;376(20):1943-55.

This article is protected by copyright. All rights reserved. 


\section{University Library}

\section{- M M I N E R VA A gateway to Melbourne's research publications}

Minerva Access is the Institutional Repository of The University of Melbourne

Author/s:

Scott, D;Duque, G;Ebeling, PR

Title:

Does obesity reduce risk for osteoporosis and fractures in older adults?

Date:

2018-01-01

Citation:

Scott, D., Duque, G. \& Ebeling, P. R. (2018). Does obesity reduce risk for osteoporosis and fractures in older adults?. INTERNAL MEDICINE JOURNAL, 48 (1), pp.104-105. https:// doi.org/10.1111/imj.13655.

Persistent Link:

http://hdl.handle.net/11343/283473 